\title{
EFFECT OF ETHANOLIC EXTRACT OF ALOE VERA (ALOE BARBADENSIS) GEL ON BLOOD GLUCOSE LEVEL OF ALLOXAN INDUCED HYPERGLYCAEMIC MICE
}

\author{
SHAMMIN HAQUE ${ }^{1}$, FERDOUS ARA ${ }^{2}$, MD. JALALUDDIN IQBAL ${ }^{3}$, HALIMA BEGUM ${ }^{4}$, NAZMUN NAHAR ALAM $^{5}$ \\ ${ }^{1}$ Assistant Professor, Department of Pharmacology \& Therapeutics, Shaheed Suhrawardy Medical College, Dhaka \\ ${ }^{2}$ Assistant Professor, Department of Anatomy, OSD, Directorate General of Health Services (DGHS), Dhaka \\ ${ }^{3}$ Professor and Head, Department of Pharmacology \& Therapeutics, Dhaka Medical College, Dhaka \\ ${ }^{4}$ Assistant Professor, Department of Pharmacology \& Therapeutics, Faridpur Medical College, Faridpur
}

\begin{abstract}
The purpose of this study was to show the antidiabetic effect of ethanolic extract of Aloe vera gel in alloxan induced hyperglycaemic mice. Ethanolic extract of Aloe vera gel was orally administered for four weeks at a dose of $300 \mathrm{mg} / \mathrm{kg}$ body weight. Weekly estimates of fasting blood glucose level in normal non-diabetic and alloxan induced hyperglycaemic mice were assessed. Ethanolic Aloe vera gel extract revealed no blood glucose lowering action upon non-diabetic mice. But, a significant reduction in blood glucose level $(p<0.001)$ was seen in diabetic mice, when compared with diabetic control. Similar results were found when compared with a standard antidiabetic drug, gliclazide. To conclude, as administration of ethanolic extract of Aloe vera gel significantly reduces blood glucose level in hyperglycaemic mice, it can optimistically emerge as a new hope in the management of diabetes mellitus.
\end{abstract}

Keywords: Ethanolic extract of Aloe vera gel; alloxan induced hyperglycaemic mice; gliclazide.

(Bangladesh J Physiol Pharmacol 2014;30(2):25-31)

\section{INTRODUCTION}

Diabetes Mellitus is a serious and increasing global health burden and estimates of prevalence are essential for appropriate allocation of resources and monitoring of trends. Epidemiological studies of adults between 20-79 years in 130 countries worldwide revealed that in 2013, 382 million people had diabetes. This number is expected to rise to 592 million by 2035 . Most people with diabetes live in low and middle income countries and will experience the greatest increase in cases of diabetes over the next 22 years. ${ }^{1}$ Bangladesh Institute of Research and Rehabilitation In Diabetes And Endocrine Metabolic Disorders (BIRDEM) carried out a recent survey which revealed the prevalence of the disease in the rural population to be about $6.8 \% .^{2}$

Population growth, ageing of populations and urbanization with a sophisticated lifestyle is likely to direct to a high prevalence of the disease in Bangladesh. These factors will create a hazard to the economic status of the national healthcare systems.

World Health Organization (WHO) fact sheet (2011), reveals that 346 million people worldwide have diabetes. In 2004, an estimated 3.4 million people died from the consequences of high blood sugar. ${ }^{3}$ Type 2

Address for correspondence: Dr. Shammin Haque, Assistant Professor, Department of Pharmacology \& Therapeutics, Dr. Sirajul Islam Medical College and Hospital, Dhaka. E mail: shammin_549@yahoo.com diabetes comprises about $95 \%$ cases worldwide. Diabetes affects 285 million adults worldwide. ${ }^{4}$ World Health Organization (WHO) projects that diabetic deaths will double between 2005 and 2030.

According to WHO (2006), Diabetes is a condition primarily defined by the level of hyperglycaemia giving rise to risk of microvascular damage (retinopathy, nephropathy and neuropathy). Moreover, it is associated with reduced life expectancy, significant morbidity due to specific diabetes related microvascular complications, increased risk of macrovascular complications (ischaemic heart disease, stroke and peripheral vascular disease) and diminished quality of life.

WHO also states that, because of poverty and lack of access to modern medicine, about $65-80 \%$ of the world's population in developing countries depends essentially on plants for primary healthcare. The suitable weather and fertile soil has provided Bangladesh a great source of medicinal plants. Many studies have confirmed the benefits of such plants with hypoglycaemic effects useful in the management of diabetes mellitus. These effects may delay the development of diabetic complications and correct the metabolic abnormalities. New bioactive drugs isolated from hypoglycaemic plants showed antidiabetic activity with more efficacy than oral hypoglycaemic agents used in clinical therapy. ${ }^{5}$ 
Recently, one of these medicinal plants which captured the attention of recent scientific research is, Aloe vera, a popular houseplant, has a long history as a multipurpose folk remedy in China, Russia, South Africa, the United States and India. Useful chemical compounds in the Aloe plant are typically isolated from two materials: latex and gel. ${ }^{6}$ Aloe vera is most commonly used to treat diabetes due to its ability to reduce blood glucose levels. $^{7}$

The word Aloe originated from the Greeks and vera means true or genuine. In Bangladesh, it is well known by the name 'Ghritakumari'. Other global popular names are 'lily of the desert', 'miracle plant' and 'silent healer'. It is widely distributed throughout the tropics and subtropics. Spring is the most suitable season for the growth of Aloe vera. Potted plant requires well-drained sandy soil and adequate light. However, they should be protected from direct sunlight and rain. Large scale agricultural production is undertaken in Pakistan, Australia, Bangladesh, Cuba, China, Mexico, India, Jamaica, Kenya and South Africa and USA.

Aloe vera plant grows upto $50-75 \mathrm{~cm}$ tall. The green leaves are fleshy with serrated edges and are 16-20 in number arranged in a dense rosette, where the upper surface is flat and lower surface convex. The leaves comprise of an outer protective covering with a yellow sap below, which is bitter in taste. The center of each leaf is filled with a viscous gel. This gel contains most of the biologically active ingredients, mainly polysaccharides (glucomannan, acemannan, mannose), antioxidant vitamins, minerals, cholesterol, salicylic acid, prostaglandin precursors and amino acids. The biological activities should be assigned to a synergistic action of the compounds contained therein rather than a single chemical substance. Ingested Aloe vera gel is able to reduce blood glucose levels and plasma triglycerides, as well as many of the secondary symptoms of diabetes that are associated with oxidative stress. $^{8}$

Population rise, inadequate supply of drugs, prohibitive cost of treatments, side effects of several allopathic drugs and development of resistance to currently used drugs have led to increased emphasis on the use of plant materials as a source of medicines for a wide variety of human ailments. Ethnobotanical information indicates that more than 800 plants are used as traditional remedies for the treatment of diabetes. ${ }^{9}$ Herbal extracts have been confirmed for its hypoglycaemic effect in humans and animals for type 2 diabetes. ${ }^{10}$ Traditional antidiabetic plants might provide new oral hypoglycaemic compounds, which can counter the high cost and poor availability of the current medicines for many rural populations in developing countries. ${ }^{11}$ It has been suggested that Aloe gel might lower blood glucose levels and have additive effects when used with anti-diabetic medicines. ${ }^{12}$ Herbal medicines might produce synergistic effects when they are used along with conventional medicines. ${ }^{13}$

The present study was carried out to investigate the effect of ethanolic Aloe vera gel extract on blood glucose level of normal and experimentally induced hyperglycaemic mice.

\section{MATERIALS AND METHODS}

The study was carried out in the Department of Pharmacology and Therapeutics of Sir Salimullah Medical College in collaboration with the Institute of Nutrition and Food Science (INFS), University of Dhaka, Bangladesh.

\section{Preparation of ethanolic extract of Aloe vera gel:}

About $6 \mathrm{~kg}$ leaves were cleaned, cut into halves and placed upside down for half an hour to allow drainage of yellow latex. Leaves were peeled, the inner clear gel was cut into small pieces and blended with 95\% ethanol. It was then placed on a large, flat steel pan, covered with a clean gauze cloth and allowed to evaporate to dryness. The residue was ground into powder which was greenish brown in colour and about $30 \mathrm{gms}$ of ethanolic extract was obtained. ${ }^{14}$

\section{Animal housing:}

Thirty healthy Swiss albino mice were purchased from the animal resource division of International Centre for Diarrhoeal Disease and Research, Bangladesh (ICDDR,B), Mohakhali. They were 8 to 10 weeks old, of both sex and weighed between 30 to $45 \mathrm{gms}$. They were housed individually in clean metallic cages in the animal house of Institute of Nutrition and Food Science, in a well ventilated room within room temperature of about $26-28^{\circ} \mathrm{C}$. The animal house was maintained under a constant light and dark cycle alternating every 12 hours. The mice were allowed to feed upon standard food pellets and drink water ad libitum, except for the overnight fast (day before blood glucose estimation). During fasting, they were allowed free access to water only. ${ }^{15}$

\section{Collection of reagents, chemicals, drug and Aloe vera plant:}

Alloxan monohydrate was purchased from Loba chemicals, India; Gliclazide as Dimerol of Drug International Pvt. Ltd. was used as positive control and fresh Aloe vera leaves were bought from a local market in Old Dhaka.

\section{Effect of ethanolic Aloe vera gel extract on blood glucose levels of non-diabetic mice;}

Twelve mice were divided into two groups with six in each group. All mice were fasted overnight before 
collection of blood to determine the fasting blood glucose level.

\section{Group A (Non-diabetic control):}

Mice were given standard mice feed and water for four weeks. Fasting blood glucose level was estimated every week during the experiment.

\section{Group B (Non-diabetic + ethanolic extract of Aloe vera):}

Mice were given ethanolic extract of Aloe vera gel (300 mg $/ \mathrm{kg}$ b.w.) orally along with mice pellets and water for four weeks. Fasting blood glucose level was estimated every week during the experiment.

\section{Effect of ethanolic Aloe vera gel extract on blood glucose level of diabetic mice:}

Eighteen mice were divided into three groups with six in each group. Alloxan (150mg/kg b.w.) was injected to induce diabetes in animals.

\section{Group C (Diabetic control group):}

Mice received standard food and water. Fasting blood glucose level was estimated before alloxan injection, $72 \mathrm{hrs}$ after alloxan to confirm diabetes induction and thereafter every week throughout the experiment.

\section{Group D (Anti-diabetic drug group):}

Gliclazide (50mg/kg b.w.) was given orally along with standard food for four weeks after confirmation of induced diabetes. Fasting blood glucose level was estimated before administration of alloxan, $72 \mathrm{hrs}$ after alloxan and every week throughout the experiment.

\section{Group E (Experimental group):}

Mice were fed with ethanolic extract of Aloe vera gel (300mg/kg b.w) orally by means of micropipette along with standard food and water for four weeks. Fasting blood glucose level was estimated before injecting alloxan, $72 \mathrm{hrs}$ after alloxan and then, every week throughout the experiment.

All animals were weighed during the fasting state, at the beginning of experiment and on the last day of treatment before sacrifice, for determination of body weight. Any clinical changes in animals during the treatment period were also observed.

\section{Collection of blood samples:}

Every week during the treatment, mice blood sample was collected from the tail vein by tail tipping for estimation of fasting blood glucose level. All animals were then sacrificed under light chloroform anesthesia after completion of treatment on the last day of experiment. Blood was obtained in eppendorf tubes and centrifuged at $5000 \mathrm{rpm}$ for 15 minutes for separation of serum. This serum was then used for biochemical analysis.

\section{Estimation of blood glucose level:}

Determination of serum glucose concentration was done by oxidase and peroxidase (GOD-POD) method using glucose estimation kit (Human, Germany) and microtiter plate reader (Multiskan EX, Labsystems, Finland).

\section{Statistical analysis:}

The results are given as mean and standard deviation for the independently performed experiments. Unpaired students' $t$ test was used to see the level of significance. $p$ value $<0.05$ was considered as statistically significant.

\section{RESULTS}

Table 1 shows the weekly estimates of blood glucose level in both non-diabetic and diabetic mice throughout the entire treatment period. There was no remarkable change in blood glucose level every week in normal control group and non-diabetic mice treated with ethanolic extract of Aloe vera gel. Blood glucose level was stable at near normal in Group B, shown as changes in percentage in Fig 1. Diabetic control mice showed a noticeable rise in blood glucose level every week. Diabetic mice treated with ethanolic extract of Aloe vera gel revealed a subsequent drop in blood glucose in the first week and then further reduction continued in the proceeding weeks. Gliclazide treated group showed similar results as Aloe vera treated diabetic group. Fig. 2 represents the corresponding weekly percentage changes in blood glucose level of the related groups. 
Table 1

Effect of ethanolic extract of Aloe vera gel and glilazide on fasting blood glucose level in non-diabetic and alloxan induced hyperglycaemic mice

\begin{tabular}{|c|c|c|c|c|c|}
\hline \multirow[t]{2}{*}{$\begin{array}{c}\text { Group } \\
(n=6)\end{array}$} & \multicolumn{5}{|c|}{$\begin{array}{l}\text { Fasting blood glucose level (mmol/L) } \\
(\text { mean } \pm \text { SD) }\end{array}$} \\
\hline & $\begin{array}{c}\text { O week } \\
\text { (after alloxan) }\end{array}$ & $1^{\text {st }}$ week & $2^{\text {nd }}$ week & $3^{\text {rd }}$ week & $4^{\text {th }}$ week \\
\hline Group A & $6.50 \pm 0.24$ & $6.01 \pm 0.37$ & $6.32 \pm 0.28$ & $6.22 \pm 0.24$ & $6.07 \pm 0.50$ \\
\hline Group B & $4.86 \pm 0.28$ & $5.34 \pm 0.23$ & $5.35 \pm 0.12$ & $5.28 \pm 0.05$ & $5.58 \pm 0.16$ \\
\hline Group C & $12.03 \pm 0.28$ & $12.35 \pm 0.28$ & $12.36 \pm 0.62$ & $12.94 \pm 0.38$ & $12.91 \pm 0.63$ \\
\hline Group D & $12.89 \pm 0.81$ & $8.35 \pm 1.03$ & $7.53 \pm 0.28$ & $6.43 \pm 0.78$ & $6.76 \pm 0.89$ \\
\hline Group E & $12.21 \pm 0.76$ & $8.97 \pm 0.49$ & $7.67 \pm 0.31$ & $6.42 \pm 0.81$ & $6.78 \pm 0.63$ \\
\hline
\end{tabular}

$\mathrm{n}$ : number of mice used

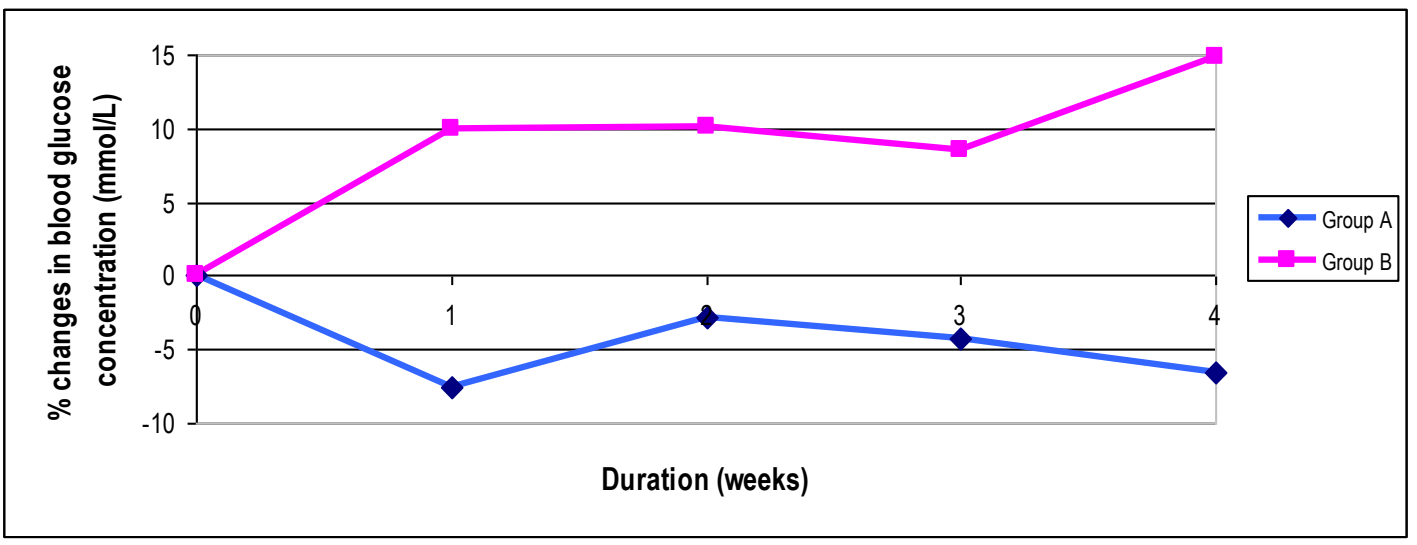

Fig. 1: Effect of ethanolic extract of Aloe vera gel on fasting blood glucose level in non-diabetic mice

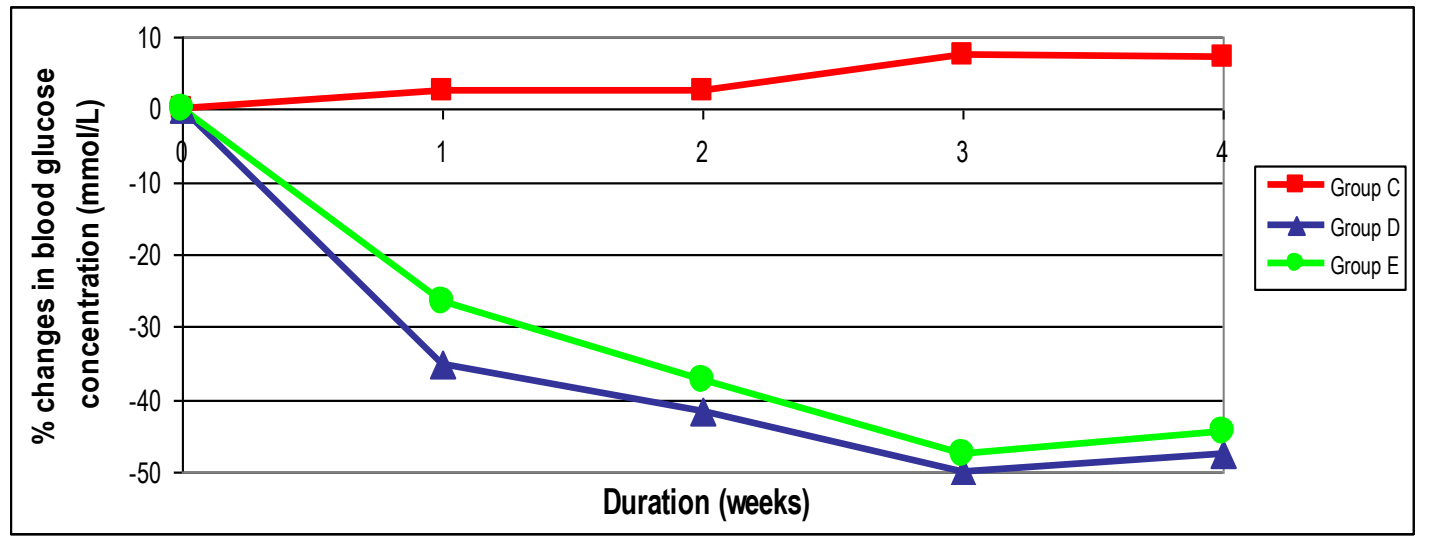

Fig. 2: Effect of ethanolic extract of Aloe vera gel and Gliclazide on fasting blood glucose level of alloxan induced hyperglycaemic mice 
Table 2 shows the effect of ethanolic extract of Aloe vera gel on fasting blood glucose level in normal non-diabetic mice. There was no significant change $(p>0.05)$ in blood glucose level in normal mice treated with ethanolic extract of Aloe vera (Group B).

Table 2

Effect of ethanolic extract of Aloe vera gel on fasting blood glucose level in non-diabetic mice

\begin{tabular}{cccc}
\hline $\begin{array}{c}\text { Group } \\
(\mathbf{n = 6})\end{array}$ & Treatment & $\begin{array}{c}\text { Fasting blood glucose } \\
\text { level }(\mathbf{m m o l} / \mathbf{L}) \\
\left(\mathbf{4}^{\mathrm{th}} \mathbf{\text { week }}\right) \\
(\mathbf{m e a n} \pm \mathbf{S D})\end{array}$ & $\begin{array}{c}\text { Level of } \\
\text { significance }\end{array}$ \\
\hline Group A & $\begin{array}{c}\text { Standard lab diet and water } \\
\text { ad libitum }\end{array}$ & $6.07 \pm 0.51$ & $\mathrm{p}>0.05^{*}$ \\
Group B & $\begin{array}{c}\text { Ethanolic extract of Aloe vera gel } \\
(300 \mathrm{mg} / \mathrm{kg} \text { b.w.) }\end{array}$ & $5.58 \pm 0.16^{n s}$ & \\
\hline
\end{tabular}

* cross-table variables and independent sample t test

$\mathrm{n}$ : number of mice used

Table 3, shows the effect of gliclazide and ethanolic extract of Aloe vera gel, Group $D$ and $E$, respectively when compared with diabetic control group. Aloe vera gel extract produced significant change $(p<0.001)$ in blood glucose level in diabetic mice compared to diabetic control (Group $C)$. Similar significant change $(p<0.001)$ was produced by the drug control (Group D). In this table, effect of ethanolic extract of Aloe vera gel in lowering the blood glucose level was compared with the group treated with gliclazide for 4 weeks and the results were not significant $(p>0.05)$. Corresponding weekly changes in percentage of blood glucose level are displayed in Fig.2.

Table 3

Effect of ethanolic extract of Aloe vera gel and gliclazide on fasting blood glucose level of alloxan induced hyperglycaemic mice

\begin{tabular}{|c|c|c|c|}
\hline $\begin{array}{l}\text { Group } \\
(n=6)\end{array}$ & Treatment & $\begin{array}{c}\text { Fasting blood glucose } \\
\text { level (mmol/L) } \\
\left(4^{\text {th }} \text { week) }\right. \\
(\text { mean } \pm \text { SD) }\end{array}$ & $\begin{array}{c}\text { Level of } \\
\text { significance }\end{array}$ \\
\hline Group C & $\begin{array}{l}\text { Standard lab diet and water } \\
\text { ad libitum }\end{array}$ & $12.91 \pm 0.63$ & $\begin{array}{l}\mathrm{p}<0.001^{*} \\
\text { C vs D }\end{array}$ \\
\hline Group D & $\begin{array}{c}\text { Gliclazide } \\
\text { (50mg/kg b.w.) }\end{array}$ & $6.76 \pm 0.89$ & $\begin{array}{l}\mathrm{p}<0.001^{*} \\
\text { C vs } \mathrm{E}\end{array}$ \\
\hline Group E & $\begin{array}{l}\text { Ethanolic extract of Aloe vera gel } \\
\qquad(300 \mathrm{mg} / \mathrm{kg} \mathrm{b.w.)}\end{array}$ & $6.78 \pm 0.63$ & $\begin{array}{l}p>0.05^{*} \\
D \text { vs } E\end{array}$ \\
\hline
\end{tabular}

* cross-table variables and independent sample t test

$\mathrm{n}$ : number of mice used

Fig. 3 shows the mean body weight of non diabetic and diabetic mice before and after the treatment period. All groups, except diabetic control group, showed an increase in mean body weight. Diabetic control group showed a reduction in body weight by $22 \%$. Ethanolic extract of Aloe vera gel caused no weight reduction both in normal and diabetic mice. The changes in body weight increased by $11.1 \%$ and $10.5 \%$, respectively. Gliclazide increased body weight by $13.8 \%$. No clinical changes in animals were observed. There was no diarrhoea, hair loss, restlessness, neither any behavioural problems. 


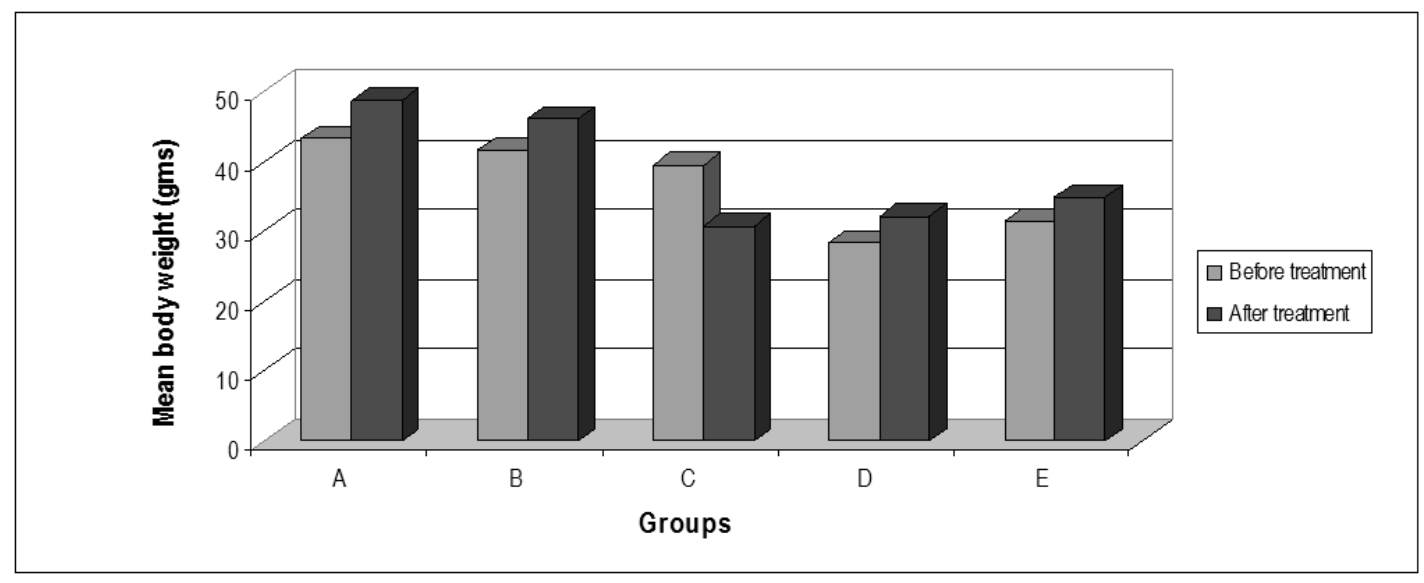

Fig. 3: Change in body weight of non-diabetic and alloxan induced hyperglycaemic mice before and after treatment with ethanolic extract of Aloe vera gel

\section{DISCUSSION}

The results of the present study shows that the ethanolic extract of Aloe vera gel has blood glucose lowering effect in alloxan induced hyperglycaemic mice, but poses no effect on blood glucose level of nondiabetic mice. Results were similar to those produced by a standard antidiabetic drug, Gliclazide.

Noor et al. ${ }^{11}$ had recorded a weekly change in fasting blood glucose level in normal, diabetic and Aloe vera treated rats. The trend in changes in blood glucose level every week are in accordance with the findings of the present study.

Absence of blood glucose lowering activity of Aloe vera gel in non-diabetic mice was also observed by other investigators. ${ }^{16}$ But the study of Jafri et al. ${ }^{17}$, do not corroborate with the findings of the present study. It could be due to the absence of aloe latex from the gel used in the present study. They ${ }^{18}$ used whole Aloe vera leaf extract including the laxative component, aloe latex, which might have reduced the blood glucose level in normal mice significantly compared to that of normal control group.

The antihyperglycaemic activity of Aloe vera gel was observed by other researchers. ${ }^{14}$ In their study, they mentioned a probable mechanism of glucose homeostasis by Aloe vera gel extract. This may be done by increased activity of hexokinase and decreased activity of glucose-6-phosphatase, lactate dehydrogenase and fructose-1,6-bisphosphatase, along with the liver glycogen level returning to near normal range. In $2007^{18}$, in another study, they represented that Aloe vera gel has a significant beneficial effect on tissue and plasma glycoprotein content (hexose, hexosamine and sialic acid) in experimentally induced diabetic rats. Consequently, this helps to prevent the development of glycoprotein mediated secondary diabetic complications.
Identification of five phytosterols from Aloe vera gel was done by Tanaka et al. ${ }^{19}$ in their research, with an aim to find out the antidiabetic compounds present in Aloe vera gel. Treatment with $1 \mu \mathrm{g}$ of the five phytosterols, lophenol, 24-methyl-lophenol, 24-ethyl-lophenol, cycloartanol and 24-methylene-cycloartanol, significantly reduced the $(\mathrm{HbA} 1 \mathrm{c})$ levels in diabetic mice. This work suggested a long term antidiabetic effect of Aloe vera gel and its phytosterols.

Oral administration of Aloe vera gel extract have antioxidative effect which is manifested by the significant decrease in serum malonaldialdehyde (MDA) levels with a significant increase in both serum nitric oxide and total antioxidant capacity in diabetic rats. It is confirm that the hypoglycaemic effect of Aloe vera gel extract may be due to the presence of some trace elements such as chromium, zinc and manganese which potentiate insulin action. ${ }^{20}$

Relationship between increase in body weight with a reduction in blood glucose level in Aloe vera treated group was also found in other related studies ${ }^{14,21}$ who reported that it may be due to enhancement of glucose metabolism by Aloe vera.

\section{CONCLUSION}

The results of this study showed that ethanolic Aloe vera gel extract is euglycaemic in experimental animals. This property might prove to be beneficial for the treatment strategy of diabetes mellitus. Developing nations may find ethanolic Aloe vera gel extract as an economical and valuable option when dealing with diabetes mellitus. If future clinical trials implement these experimental data, ethanolic Aloe vera gel extract may materialize as a substitute crude source or as an adjuvant therapy for type II diabetes. 


\section{REFERENCES}

1. Guariguata L., Whiting D.R., Hambleton I., Beagley J., Linnenkamp U, Shaw J.E. Global estimates of diabetes prevalence for 2013 and projections for 2035 available at http://www.sciencedirect.com/science/article/pii/S0168822713003 859 accessed on 24-10-14.

2. Rahim M.A., Hussain A., Khan A.K.A., Sayeed M.A., Ali S.M.K., Vaaler S. Rising prevalence of type 2 diabetes in rural Bangladesh: A population based study. Diabetes Research and Clinical Practice 2007; 77(2):300-305.

3. WHO fact sheet on diabetes available at http://www.who.int/mediacentre/factsheets/fs312/en/index accessed on 26-1-12.

4. Diabetes Care (2012); 35: 193-195 available at www.care.diabetesjournal.org accessed on 20-2-12.

5. Bnouham M., Ziyyat A., Mekhfi H., Tahri A., Legssyer A. Medicinal plants with potential antidiabetic activity - A review of ten years of herbal medicine research (1990-2000). International Journal of Diabetes and Metabolism 2006; 14:1-25.

6. Modak M., Dixit P., Londhe J., Ghaskabdi S., Paul A. Devasaqayam T. Indian herbs and herbal drugs used for the treatment of diabetes 2007; 40(3):163-173.

7. Creque K.C.A., Junker M. and Yevtukh M., Medical Attributes of Aloe vera - The Aloe Plant (2009) available at http://klemow.wilkes.edu/Aloe09.html accessed on 5-22012.

8. About aloe vera plant available at www.aloeveragarden.com accessed on 5-2-2012.

9. Rajasekaran S., Ravi K., Sivagnanam K. and Subramanian S. Beneficial effects of Aloe vera gel extract on lipid profile status in rats with streptozotocin diabetes. Clinical and Experimental Pharmacology and Physiology 2006; 33: 232-237.

10. Afaf I., Abuelgasim, Maha K.M., Osman and B. Elmahdi. Effects of Aloe vera (Elsabar) ethanolic extract on blood glucose level in Wistar Albino Rats. Journal of Applied Sciences Research 2008; 4(12):1841-1845.

11. Noor A., Vijayalakshmi M.A., Gunasekaran S., Manickam A.S. Antidiabetic activity of Aloe vera and histology of organs in streptozotocin-induced diabetic rats. Current Science 2008; 94(8):1070-1076.

12. Bush TM, Rayburn KS, Holloway SW, Sanchez-Yamamoto DS Allen BL, Lam $\mathrm{T}$, So BK, Tran de $\mathrm{H}$, Greyber ER, Kantor $\mathrm{S}$, Roth LW. Adverse interactions between herbal and dietary substances and prescription medications: a clinical survey 2007; 13 (2): 30-5.

13. Rodriguez-Fragoso L, Reyes-Esparza J, Burchiel S, Herrera-Ruiz D and Torres E. Risks and benefits of commonly used herbal medicines in Mexico. Toxicology Applied Pharmacology 2007; 10:1-16.

14. Rajasekaran S., K. Sivagnanam, K. Ravi, and S. Subramanian. Hypoglycemic Effect of Aloe vera Gel on Streptozotocin-Induced Diabetes in Experimental Rats. J Med Food 2004; 7(1): 61-66.

15. Kim K, Kim H, Kwon J, Lee S, Kong H, Im SA, Lee YH, Lee CK, Lee $\mathrm{R}$, Oh ST, Jo TH, Park YI. Hypoglycemic and hypolipidemic effects of processed Aloe vera gel of non-insulin dependent diabetes mellitus. Phytomedicine 2009 available at www.sciencedirect.com accessed on 5-2-12.

16. Afaf, Abuelgasim I., Maha, Osman K.M. and Elmahdi. Effects of Aloe vera (Elsabar) Ethanolic Extract on blood glucose level in Wistar Albino rats. Journal of Applied Sciences Research 2008; 4(12):1841-1845.
17. Jafri S.A., Hasan S.S., Nadeem A., Kalsoom, Iqbal J. Hypoglycaemic Efffect Of Aloe Vera Extract In Alloxan-Induced Diabetic Albino Rats. Medical Journal of Islamic World Academy of Sciences 2011; 19(3):127-130.

18. Rajasekaran S. and Sathishsekar S. Therapeutic evaluation of Aloe vera gel extract on glycoprotein components in rats with streptozotocin diabetes. Journal of Pharmacology and Toxicology 2007; 2(4): 380-385.

19. Tanaka M., Misawa E., Ito Y., Habara N., Nomaguchi K., Yamada M., Toida T., Hayasawa H., Takase M., Inagaki M. and Higuchi R. Identification of Five Phytosterols from Aloe Vera Gel as Antidiabetic Compounds. Biol. Pharm. Bull. 2006; 29(7):1418-1422.

20. Enas Ali Kamel Mohamed. Antidiabetic, Antihypercholestermic and Antioxidative Effect of Aloe Vera Gel Extract in Alloxan Induced Diabetic Rats. Australian Journal of Basic and Applied Sciences 2011; 5(11): 1321-1327.

21. Nwanjo H.U. Antioxidant activity of the exudate from Aloe barbadensis leaves in diabetic rats. Biokemistri 2006; 18:77-81. 